\title{
Environmental response to the cold climate event 8200 years ago as recorded at Højby Sø, Denmark
}

\author{
Peter Rasmussen, Mikkel Ulfeldt Hede, Nanna Noe-Nygaard, Annemarie L. Clarke \\ and Rolf D. Vinebrooke
}

The need for accurate predictions of future environmental change under conditions of global warming has led to a great interest in the most pronounced climate change known from the Holocene: an abrupt cooling event around 8200 years before present (present $=$ A.D. 1950), also known as the ' 8.2 ka cooling event' ( $\mathrm{ka}=$ kilo-annum $=1000$ years). This event has been recorded as a negative $\delta^{18} \mathrm{O}$ excursion in the central Greenland ice cores (lasting 160 years with the lowest temperature at 8150 B.P.; Johnsen et al. 1992; Dansgaard 1993; Alley et al. 1997; Thomas et al. 2007) and in a variety of other palaeoclimatic archives including lake sediments, ocean cores, speleothems, tree rings, and glacier oscillations from most of the Northern Hemisphere (e.g. Alley \& Ágústsdóttir 2005; Rohling \& Pälike 2005). In Greenland the maximum cooling was estimated to be $6 \pm 2^{\circ} \mathrm{C}$ (Alley et al. 1997) while in southern Fennoscandia and the Baltic countries pollenbased quantitative temperature reconstructions indicate a maximum annual mean temperature decrease of around $1.5^{\circ} \mathrm{C}$ (e.g. Seppä et al. 2007).

Today there is a general consensus that the primary cause of the cooling event was the final collapse of the Laurentide ice sheet near Hudson Bay and the associated sudden drainage of the proglacial Lake Agassiz into the North Atlantic Ocean around 8400 B.P. (Fig. 1; Barber et al. 1999; Kleiven et al. 2008). This freshwater outflow, estimated to amount to $c .164,000 \mathrm{~km}^{3}$ of water, reduced the strength of the North Atlantic thermohaline circulation and thereby the heat transported to the North Atlantic region, resulting in an atmospheric cooling (Barber et al. 1999; Clark et al. 2001; Teller et al. 2002). The climatic consequences of this meltwater flood are assumed to be a good geological analogue for future climate-change scenarios, as a freshening of the North Atlantic is projected by almost all global-warming models (e.g. Wood et al. 2003; IPCC 2007) and is also currently being registered in the region (Curry et al. 2003).

In an ongoing project, the influence of the $8.2 \mathrm{ka}$ cooling event on a Danish terrestrial and lake ecosystem is being investigated using a variety of biological and geochemical proxy data from a sediment core extracted from Højby $S_{\varnothing}$, north-west Sjælland (Fig. 2). Here we present data on changes in lake hydrology and terrestrial vegetation in response to climate change, inferred from macrofossil data and pollen analysis, respectively.

\section{Materials and methods}

Højby Sø is located in Odsherred, north-west Sjælland, approximately $2.5 \mathrm{~km}$ from the sea. Today the lake has a surface area of $c .40$ ha with a mean water depth of $1.8 \mathrm{~m}$. The lake has no natural inlets or outlets. In 2005 a $13.6 \mathrm{~m}$ long sediment

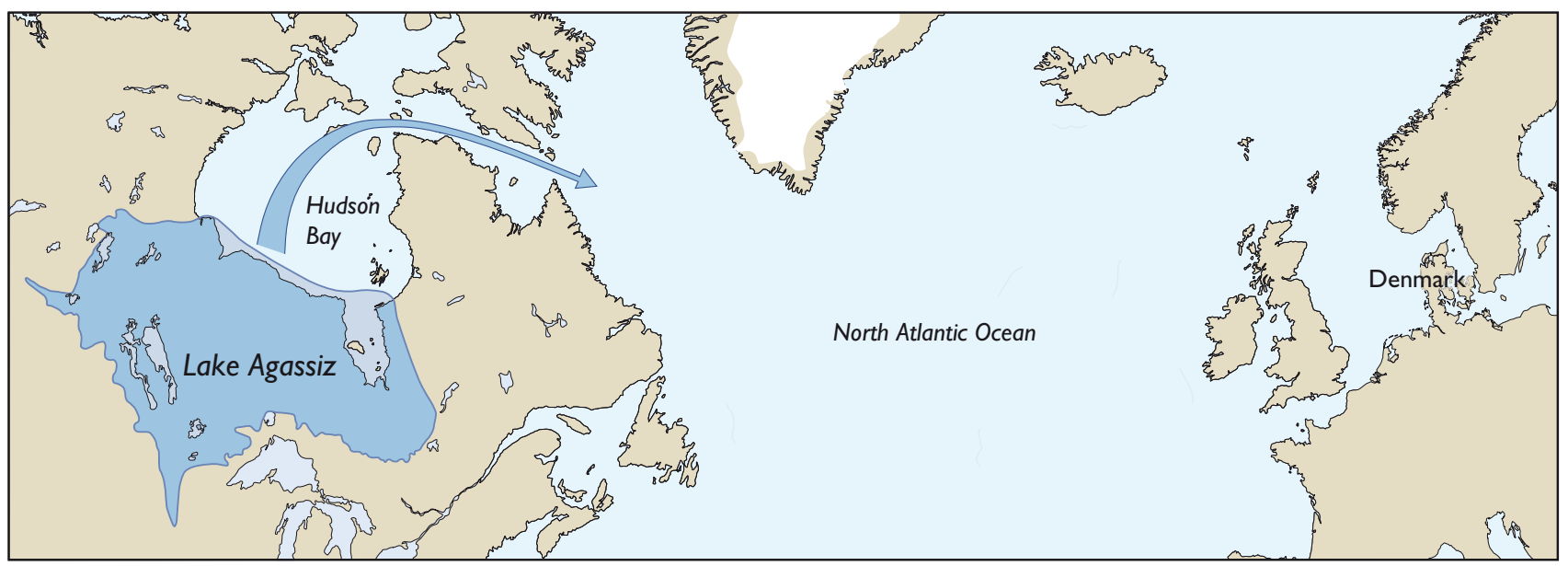

Fig. 1. Map showing Lake Agassiz in North America and the route of the meltwater outburst into Hudson Bay and the North Atlantic Ocean when the lake drained at about 8400 B.P. (modified from Kleiven et al. 2008). 


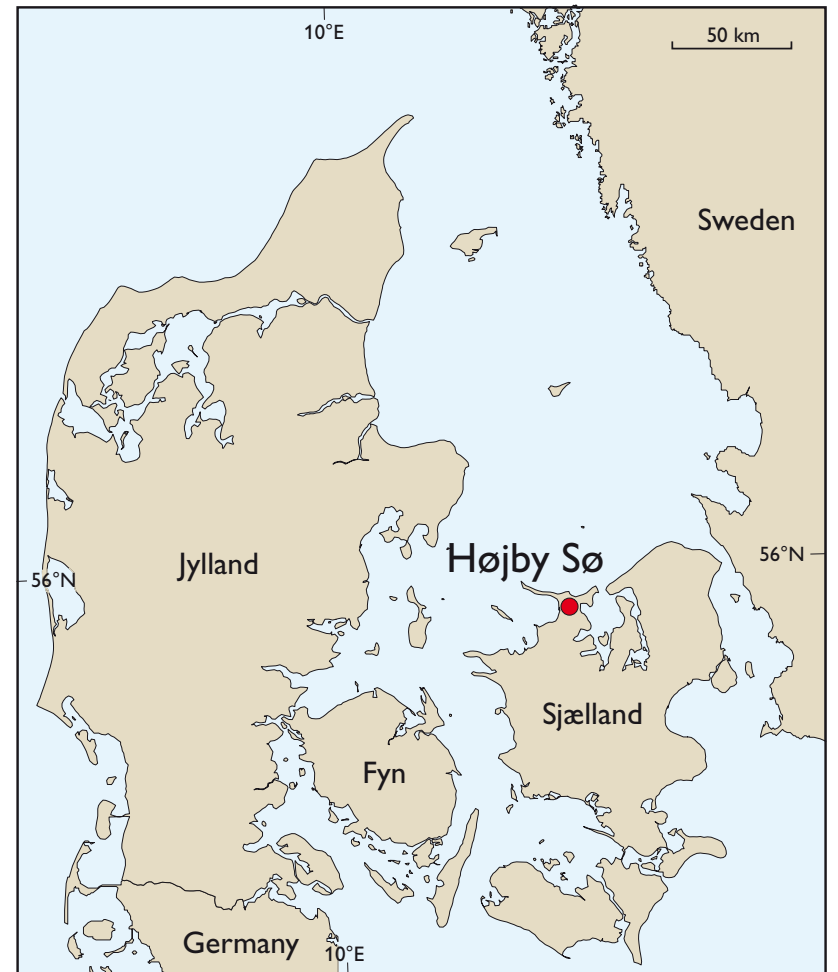

Fig. 2. Map of Denmark showing the location of Højby $\$ \varnothing$ in north-west Sjælland.

core consisting mainly of calcareous gyttja was retrieved from the lake. From the entire core 28 samples were dated by Accelerator Mass Spectrometry (AMS) ${ }^{14} \mathrm{C}$ using terrestrial plant material. The whole sediment sequence covers the time period c. 12,000-2000 years B.P.; here we focus on time slices of relevance to the $8.2 \mathrm{ka}$ cooling event. The core content of plant and animal macrofossils is shown as accumulation rates. Pollen data were calculated as percentages, concentrations (grains $/ \mathrm{cm}^{3}$ ) and accumulation rates (grains $/ \mathrm{cm}^{2}$ per year); only the accumulation rate data are presented here. At least 500 pollen grains from terrestrial plants were counted per sample.

\section{Results and discussion}

\section{Lake hydrology and climate change}

Sedimentary macrofossil data can be used as proxy evidence for changes in catchment and lake hydrology (e.g. Hannon \& Gaillard 1997). At Højby Sø the abundance of macrophyte remains - Ceratophyllum (hornwort), Nymphaea (white water-lily), Nuphar (yellow water-lily), Najas marina (hollyleaved naiad), Chara (stonewort) - and Daphnia resting eggs (ephippia) exhibits an abrupt increase around 8400 B.P. (Fig. 3 ). This pronounced change testifies to a sudden precipitation-induced lake level rise, as a higher water table would, on the one hand, result in an extension of shallow areas suitable for macrophyte growth, and on the other hand enhance conditions for the pelagic-living Daphnia. This inferred change to moist conditions and increased lake level are supported by simultaneous and marked increases in sediment accumulation rates of minerogenic matter and the alga Pediastrum (not illustrated). These data from Højby Sø add to the growing evidence that the brief $8.2 \mathrm{ka}$ cooling event observed and defined in the Greenland ice cores (8247-8086 B.P.; Thomas et al. 2007) took place during a period of longer-term climatic perturbation which started some hundred years earlier (e.g. Rohling \& Pälike 2005; Lal et al. 2007). Interestingly, the start of the moist climatic period inferred from Højby $\mathrm{S} \varnothing$ (c. 8400 B.P.) is contemporary (within dating uncertainties) with the weakening of the thermohaline circulation (Kleiven et al. 2008) and a global $\mathrm{CO}_{2}$ decline of c. 25 ppmv as inferred from stomata analysis from Lille Gribsø, north-east Sjælland (Wagner et al. 2002).

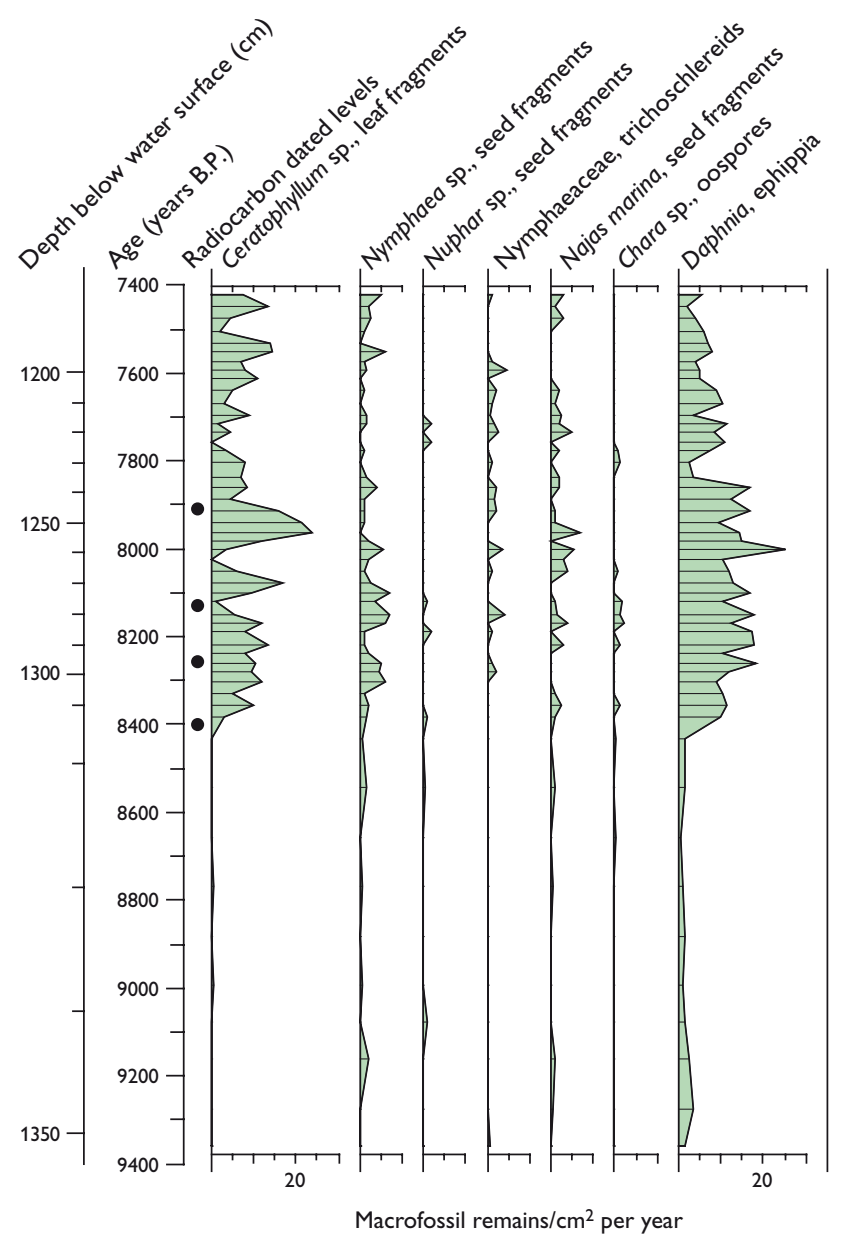

Fig. 3. Macrofossil accumulation diagram (remains $/ \mathrm{m}^{2}$ per year) from Højby Sø covering the time period c. 9400-7400 years B.P. Only selected taxa are shown. The age-depth model will be published in a forthcoming paper. 

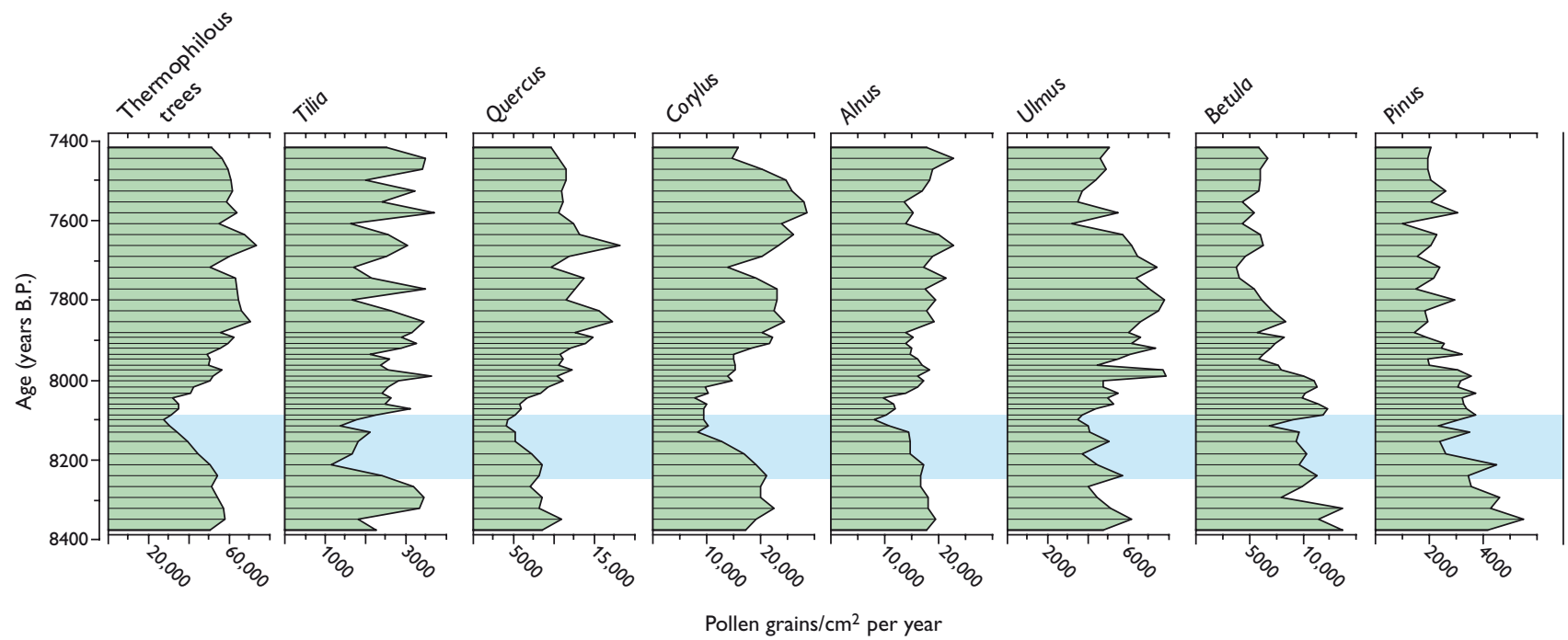

Fig. 4. Pollen accumulation rates (grains $/ \mathrm{cm}^{2}$ per year) of sum of thermophilous trees and dominant tree taxa at $\mathrm{H} \varnothing \mathrm{jby} \mathrm{S} \varnothing$ during the time interval $c$. 8400-7400 B.P. Note different horizontal scales. The time period of the $8.2 \mathrm{ka}$ cooling event according to the Greenland ice core chronology is indicated by blue (8247-8086 B.P.; Thomas et al. 2007).

\section{Vegetation and climate change}

Figure 4 illustrates the pollen accumulation rates for selected tree taxa and groups of taxa at Højby $\mathrm{S}_{\varnothing}$ in the time interval $8400-7400$ years B.P. In this study period the overall trends in the pollen data are similar whether calculated as accumulation rates, percentages or concentrations. In the Atlantic chronozone (9000-5900 years B.P.), the Danish landscape was characterised by broad-leaved, closed-canopy woodlands, also called the 'stable primeval forest' (Iversen 1973). Within the dating uncertainty of our chronology the pollen stratigraphy at Højby Sø provides clear evidence for vegetational disturbances coeval with the $8.2 \mathrm{ka}$ cooling event. Between $c$. 8250 and 7900 years B.P. there is a pronounced decline and subsequent recovery in the pollen accumulation rates for Tilia (lime), Quercus (oak), Corylus (hazel) and Alnus (alder). The beginning of the decline in each of the mentioned taxa and the subsequent recovery are as follows: Tilia $c .8250 / 8100$ B.P., Quercusc. $8200 / 8000$ B.P., Corylus c. $8250 / 7900$ B.P. and Alnus c. 8100/8000 B.P. By contrast, Ulmus (elm) accumulation rates are more variable and do not show a similarly clear decrease, although the taxon has a minimum frequency about 8100 B.P. Two taxa, Betula (birch) and Pinus (pine), exhibit a clear maximum in the time interval c. 8100-8000 B.P. Our data suggest that the primary response to the $8.2 \mathrm{ka}$ cooling event was a decrease in the total pollen accumulation rates of thermophilous ('warm-loving'), deciduous tree taxa in the time period c. $8200-8000$ B.P. (Fig. 4). This tree pollen recession is probably not a reflection of reduced forest cover as the abundance of open ground herbs - e.g. Artemisia (mugwort), Rumex acetosella (sheep's sorrel) and Poaceae (grasses) - does not exhibit a contemporary increase (not illustrated). As dis- cussed by several authors, the decrease in pollen abundance of a number of thermophilous broad-leaved tree taxa during the 8.2 ka cooling event need not be synonymous with a change in population size. Instead it might, solely or partly, represent reduced pollen production due to unfavourable climatic conditions (e.g. Snowball et al. 2002; Seppä et al. 2007). The various taxa referred to above do not respond simultaneously to changing environmental conditions, which might be due to differences in their physiological tolerance towards changes in, for example, temperature and hydrology. The decrease in pollen accumulation rates for Tilia and Quercus, which flower in July and May/June respectively, strongly suggests that the forest ecosystem in our study area was stressed by low temperatures during the summer season. Many European palaeoclimate records and model simulations indicate that the temperature drop during the $8.2 \mathrm{ka}$ cooling event was primarily a winter and early spring phenomenon (Alley \& Ágústsdóttir 2005; Wiersma \& Renssen

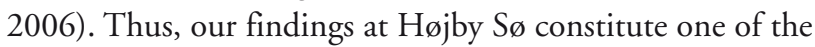
rare examples of the $8.2 \mathrm{ka}$ cooling event also being a summer phenomenon.

The decline in the pollen accumulation rates of the early flowering taxa Corylus, Alnus and Ulmus (start flowering February-April) was most likely caused by long winters with late spring frosts that would have damaged flowers and catkins, leading to a reduction in pollen productivity. Increases in pollen accumulation rates for Betula and Pinus during the $8.2 \mathrm{ka}$ cooling event are presumably due to the fact that these two taxa are the most frost-resistant tree taxa in northern Europe. However, the fact that the accumulation rates for the latter taxa actually increase compared to levels 
immediately before the cooling event, is cause for speculation. The elevated accumulation rates during the $8.2 \mathrm{ka}$ cooling event might reflect an increase in actual population size and not just an increase in pollen productivity. If this is correct, the cause of the population expansion could be a hydrological change towards drier conditions. This hypothesis finds some support in the clear inverse relationship between the decrease in Alnus and the increase in Betula and Pinus, suggesting a causal link between these taxa. Alnus is a tree usually associated with damp or waterlogged soils and therefore sensitive to changes in the water table; the Alnus decrease might therefore, solely or partly, be related to a water-level lowering in this period, and with an exposure of the former littoral zone around the lake Betula and Pinus may have expanded into this habitat.

\section{Conclusions and future work}

Due to good chronological control (not presented here) combined with high sampling resolution of the sediment

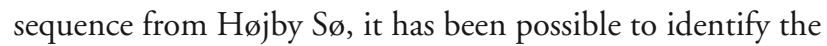
8.2 ka cooling event in a Danish palaeo-record. The pollen data reveal that the forest ecosystem was affected by low temperatures during both the summer and winter - early spring; the result was reduced pollen production from thermophilous, deciduous trees. Possible changes in population size due to climatic-induced hydrological changes are also suggested. Furthermore, our investigation indicates that the short $8.2 \mathrm{ka}$ cooling event took place during a period of longer-term climatic deterioration which started around 8400 B.P., coeval with the catastrophic drainage of Lake Agassiz. Using diatom and algal pigment analyses, ongoing work in the Højby Sø project aims to explore if and how the aquatic ecosystem responded to the climate change 8200 B.P.

\section{Acknowledgements}

Geocenter Copenhagen and the Carlsberg Foundation are gratefully acknowledged for financial support.

\section{References}

Alley, R.B. \& Ágústsdóttir, A.M. 2005: The 8k event: cause and consequences of a major Holocene abrupt climate change. Quaternary Science Reviews 24, 1123-1149.
Alley, R.B., Mayewski, P.A., Sowers, T., Stuiver, M., Taylor, K.C. \& Clark, P.U. 1997: Holocene climate instability: a prominent widespread event 8200 years ago. Geology 25, 483-486.

Barber, D.C. et al. 1999: Forcing of the cold event 8,200 years ago by catastrophic drainage of Laurentide lakes. Nature 400, 344-348.

Clark, P.U., Marshall, S.J., Clarke, G.K.C., Hostetler, S.W., Licciardi, J.M. \& Teller, J.T. 2001: Freshwater forcing of abrupt climate change during the last glaciation. Science 293, 283-287.

Curry, R., Dickson, B. \& Yashayaev, I. 2003: A change in the freshwater balance of the Atlantic Ocean over the past four decades. Nature $\mathbf{4 2 6}$, 826-829.

Dansgaard, W. 1993: Evidence for general instability of past climate from a 250-kyr ice core record. Nature 364, 218-220.

Hannon, G.E. \& Gaillard, M.-J. 1997: The plant-macrofossil record of past lake-level changes. Journal of Paleolimnology 18, 15-28.

IPCC (Intergovernmental Panel on Climate Change) 2007: Climate Change 2007. (www.ipcc.ch).

Iversen, J. 1973: The development of Denmark's nature since the last glacial. Danmarks Geologiske Undersøgelse V. Række 7-C, 126 pp.

Johnsen, S.J., Clausen, H.B., Dansgaard, W., Fuhrer, K., Gundestrup, N., Hammer, C.U., Iversen, P., Jouzel, J., Stauffer, B. \& Steffensen, J.P. 1992: Irregular glacial interstadials recorded in a new Greenland ice core. Nature 359, 311-313.

Kleiven, H.F., Kissel, C., Laj, C., Ninnemann, U.S., Richter, T.O. \& Cortijo, E. 2008: Reduced North Atlantic deep water coeval with the glacial Lake Agassiz freshwater outburst. Science 319, 60-64.

Lal, D., Large, W.G. \& Walker, S.G. 2007: Climatic forcing before, during, and after the $8.2 \mathrm{Kyr}$ B.P. global cooling event. Journal of Earth System Science 116, 171-177.

Rohling, E.J. \& Pälike, H. 2005: Centennial-scale climate cooling with a sudden cold event around 8,200 years ago. Nature 434, 975-979.

Seppä, H. et al. 2007: Spatial structure of the 8200 cal yr BP event in northern Europe. Climate of the Past 3, 225-236.

Snowball, I., Zillén, L. \& Gaillard, M.-J. 2002: Rapid early-Holocene environmental changes in northern Sweden based on studies of two varved lake-sediment sequences. The Holocene 12, 7-16.

Teller, J.T., Leverington, D.W. \& Mann, J.D. 2002: Freshwater outbursts to the oceans from glacial lake Agassiz and their role in climate change during the last deglaciation. Quaternary Science Reviews 21, 879-887.

Thomas, E.R., Wolff, E.W., Mulvaney, R., Steffensen, J.P., Johnsen, S.J., Arrowsmith, C., White, J.W.C., Vaughn, B. \& Popp, T. 2007: The 8.2 ka event from Greenland ice cores. Quaternary Science Reviews 26, $70-81$.

Wagner, F., Aaby, B. \& Visscher, H. 2002: Rapid atmospheric CO2 changes associated with the 8,200-years-B.P. cooling event. Proceedings of the National Academy of Sciences of the United States of America 99, 12,011-12,014.

Wiersma, A.P. \& Renssen, H. 2006: Model-data comparison for the $8.2 \mathrm{ka}$ BP event: Confirmation of a forcing mechanism by catastrophic drainage of Laurentide lakes. Quaternary Science Reviews 25, 63-88.

Wood, R.A., Vellinga, M. \& Thorpe, R. 2003: Global warming and thermohaline circulation stability. Philosophical Transactions of the Royal Society A361, 1961-1974.

\footnotetext{
Authors' addresses

P.R., Geological Survey of Denmark and Greenland. Øster Voldgade 10, DK-1350 Copenhagen K, Denmark. E-mail: per@geus.dk M.U.H. \& N.N.-N., Department of Geography and Geology, University of Copenhagen, Øster Voldgade 10, DK-1350 Copenhagen K, Denmark. A.L.C., APEM Manchester Lab, Riverview, A17 Embankment Business Park, Heaton Mersey, Stockport, SK4 3 GN, UK. R.V., Department of Biological Science - Freshwater Biodiversity Laboratory, University of Alberta, Edmonton, Alberta T6G 2E9, Canada.
} 